\title{
SEX DIFFERENCES IN LIVER GENE EXPRESSION IN WT AND SF-1 KNOCKOUT MICE
}

\author{
Katja Kozinc Klenovsek, ${ }^{1}$ Tanja Spanic ${ }^{1}$, Gregor Majdic ${ }^{1,2}$ \\ ${ }^{1}$ Institute for preclinical studies, Department for Biochemistry, Molecular Biology and Genetics, Veterinary Faculty, University of Ljubljana, \\ Ljubljana, ${ }^{2}$ Institute of Physiology, Medical School, University of Maribor, Maribor, Slovenia \\ ${ }^{*}$ Corresponding author, E-mail: gregor.majdic@vf.uni-lj.si
}

\begin{abstract}
Liver development and function are dependent on specific gene expression profile. Many genes in the liver are differentially expressed between females and males and these sex differences are thought to be at least partially influenced by sex specific patterns of growth hormone secretion. The aim of this study was to examine whether sex chromosomes contribute to sex differences in the liver gene expression. Expression of Cyp4a10, Cyp2u1, Cux2and Hsd3b5, which are known to be differentially expressed between sexes in adulthood, were studied in WT and SF-1 knockout mice. Steroidogenic factor 1 knockout (SF-1 KO) mice that are born without gonads were used to determine whether there are any sex differences in the gene expression even in the absence of exposure to sex steroid hormones. Gonadectomised mice were also compared to gonadally intact mice and gene expression of studied genes was examined during estrous cycle in gonadally intact female mice. Higher expression of Cux2 and Cyp4a10 was detected in gonadally intact WT females in comparison to gonadally intact WT males and higher expression of $C y p 2 u 1$ and $H s d 3 b 5$ was detected in gonadally intact WT males in comparison to gonadally intactWT females. There were no sex differences in the expression of studied genes between WT gonadectomised and SF-1 KO mice. The results of our study therefore suggest that sex differences in the liver gene expression of the four studied genes are solely dependent on sex hormones and are not influenced by sex chromosome complement.
\end{abstract}

Key words: sex difference; liver; gene expression; sex steroid hormones; sex chromosomes

\section{Introduction}

Liver is one of the largest and the most important organs in the body that performs numbers of essential functions for life. It is involved in a variety of physiological functions including metabolizing carbohydrates, proteins and lipids, producing bile acids, forming plasma proteins and filtering harmful substances from the blood. Development and functioning of such a complex organ is dependent on specific gene expression profile (1). Several studies

Received:22 May 2017

Accepted for publication: 13December 2017 have shown that mammalian liver is also a sexually dimorphic organ, exhibiting major sex differences in drug and lipid metabolism and some other functions (2-5). Sex differences in liver function are present in the expression of cytochromes P450 (Cyp) and other drug-metabolizing enzymes (5). Over 1000 genes were shown to be differentially expressed between male and female liver by microarray studies and these sex differences are thought to be regulated primarily by sex specific patterns of pituitary growth hormone $(\mathrm{GH})$ secretion $(6,7)$, which is regulated by estrogens' secretion in adult females and by androgens neonatally and during adulthood in males (8). 
$\mathrm{GH}$ acts through signal transducer and activator of transcription STAT5b (3) and hepatocyte enriched nuclear factor HNF4 (7). Both these transcription factors are involved in the regulation of expression of many genes expressed in the liver and most likely contribute to the sexually dimorphic gene expression in the liver $(7,9)$.

Steroidogenic factor 1 (SF-1), officially designated NR5a1, is a nuclear receptor that was initially discovered as a regulator of the cytochrome P450 steroid hydroxylase family of enzymes (10). SF-1 plays a role in the regulation of a number of genes involved in gonadal and adrenal development, reproduction and steroidogenesis (11). Mice lacking SF-1 gene, SF-1 knockout (KO) mice, are born without adrenal glands and gonads, and exhibit male to female sex reversal $(12,13)$. Both male and female SF-1 KO mice are thus phenotypically females, although with different sex chromosome complement. Due to adrenal agenesis, SF-1 KO mice die shortly after birth, but could be rescued by corticosteroid replacement therapy followed by adrenal transplantation (14). Because SF-1 KO mice are born without gonads, they represent an important tool that allows studies of gonadal hormone-independent sexual differentiation in different tissues, including liver gene expression.

In the present study sex specific gene expression of two cytochrome $\mathrm{P} 450$ genes (Cyp4a10 and Cyp2u1), transcriptional regulator Cux2 and enzyme Hsd3b5 was examined in agonadal SF-1 $\mathrm{KO}$ mice to establish whether sex differences in liver gene expression are solely dependent on the secretion of gonadal hormones, or are some differences caused by sex chromosome complement. All studied genes have been shown before to have significant sex specific differences in the expression in adult mice. Cyp4a10 $(6,15-$ 17) and $\operatorname{Cux} 2(6,18)$ are thus expressed at the higher levels in female livers while Cyp2u1 $(6,16)$ and $H s d 3 b 5(6,19)$ show male specific expression pattern.

\section{Materials and methods}

\section{Animals}

All animal experiments were done according to ethical principles and in accordance to the EU directive (2010/63/EU) and were approved by the Administration of the Republic of Slovenia for Food Safety, Veterinary Sector and Plant Protection (license number U34401-22/2015/4).

Mice were bred and housed in the animal facility at Institute for preclinical studies, Department for Biochemistry, Molecular Biology and Genetics, Veterinary Faculty, University of Ljubljana under standard laboratory conditions (temperature 20-25 ${ }^{\circ} \mathrm{C}$, humidity 40-60 \%) and 12:12 dark/ light cycle. Mice were housed in plastic cages on bedding of wood chips (Lignocel, Rosenberg, Germany) with phytoestrogens-free diet (No. 2916; Harlan Teklad, Milan, Italy) and water ad libitum.

Heterozygous mice with a disrupted $S f-1$ (Nr5a1) allele (D2.129P2(B6)-Nr5a1; SF-1/-) were mated to produce SF-1 KO (SF-1/-) and control WT $\left(\mathrm{SF}-1^{+/+}\right)$offspring. To ensure survival of SF-1 KO mice, all newborn pups were genotyped and rescued as described before $(12,14)$.

After weaning, some WT mice were castrated (CAS) or ovariectomized (OVX) prior to puberty between postnatal days 21-25. For gonadectomy, WT mice were anesthetized with mixture of ketamine(Vetoquinol Biowet, Gorzów Wielkopolski, Poland; $100 \mathrm{\mu g} / \mathrm{g}$ body weight (BW)), xylazine (Bioveta, Ivanovice na Hané, Czech Republic; 10 $\mu \mathrm{g} / \mathrm{g} \mathrm{BW}$ ) and acepromazine (Vetoquinol, Lure, France; $2 \mu \mathrm{g} / \mathrm{g}$ BW) subcutaneously. Testes were removed through bilateral incisions (CAS), and ovaries through a single medial incision (OVX). After gonadectomy, animals received 2 injections of analgesic butorphanol (Richter Pharma AG, Wels, Austria; $3 \mathrm{mg} / \mathrm{kg} \mathrm{BW)} \mathrm{in} \mathrm{4-hour} \mathrm{interval.}$ For control to gonadectomy, SF-1 KO animals were sham operated at the same age. After surgery animals of the same chromosomal sex were housed together until the time of sacrifice. Gonadally intact WT females were sacrificed at different stages of estrous cycle (proestrus, estrus, metestrus and diestrus), which were determined by vaginal smear cytology.

Mice 5 to 7 months old were euthanized to obtain the liver tissue. Previous studies have shown that there is small effect of age on liver gene expression in adult mice and rats $(20,21)$ and therefore, we predicted that 5 to 7 months span should not affect the results. Animals were euthanized with $\mathrm{CO}_{2}$ and a sample of right hepatic lobe was taken. Livers were snap frozen in liquid nitrogen and then stored at $-80{ }^{\circ} \mathrm{C}$ until RNA isolation. 


\section{RNA isolation and quantitative RT PCR}

Total RNA was isolated from frozen individual liver tissue samples using TRIzol ${ }^{\circledR}$ reagent according to the manufacturer's instructions (Invitrogen, Carlsbad, California, USA). RNA concentration and quality were determined on Nanodrop ${ }^{\mathrm{TM}}$ Lite Spectrophotometer (Thermo Scientific, Wilmington, Delaware, USA). RNA was transcribed to cDNA using a high-capacity cDNA reverse transcription kit (Applied Biosystems, Foster City, California, USA) and then stored at $-20{ }^{\circ} \mathrm{C}$ until next use. Dilution of cDNA was prepared with nuclease free water. Quantitative real-time PCR (RT-qPCR) was done on the ABI 7300 Real-Time PCR System (Applied Biosystems) using TaqMan ${ }^{\circledR}$ Universal Master Mix II, with UNG (Applied Biosystems) and with ROX reference dye. RT-qPCR reactions were conducted in triplicates. Ten nanograms of cDNAs were used with commercial TaqMan Gene Expression Assays for genes: Hsd3b5, Cyp2u1, Cyp4a10 and Cux2, and Gapdh and Actb as internal controls (Applied Biosystems). All probes had a FAM ${ }^{\mathrm{TM}}$ dye label on the 5' end and minor groove binder (MGB) and nonfluorescent quencher (NFQ) on the 3' end. The cycling conditions were as follows: an initial 50 ${ }^{\circ} \mathrm{C}$ for 2 minutes and then $90{ }^{\circ} \mathrm{C}$ for 10 minutes, followed by 40 cycles of $95^{\circ} \mathrm{C}$ for $15 \mathrm{sec}, 60^{\circ} \mathrm{C}$ for 1 minute. To determine the $\mathrm{Ct}$ (threshold cycle) for each amplification reaction 7300 System Software was used.

All data were analyzed using the Pfaffl method as previously described (22). Two reference genes (housekeeping genes: Gapdh and Actb) were used to determine the normalization factor from geometric mean of their expression levels for every sample (23). To calculate normalized expression level of all four genes of interest, relative quantity for every sample of every gene were divided with corresponding normalization factor.

\section{Statistical analysis}

Statistical analyses were performed using the NCSS software (NCSS, Kaysville, Utah, USA). Results of gene expression study were compared using planned comparison ANOVA, followed by posthoc Fisher LSD test. All data are presented as mean \pm S.E.M. and statistical significance was considered at $\mathrm{p}<0.05$.

\section{Results}

\section{Cux2}

As expected, the expression of Cux2 was higher in gonadally intact WT females than in gonadally intact WT males $(\mathrm{p}<0.001)$. The expression of Cux2 did not differ significantly between different stages of the estrous cycle in gonadally intact WT females. Absence of gonads significantly reduced the level of expression in both WT ovariectomized females and SF-1 KO females $(p<0.001)$ with no significant difference between WT OVX and SF-1 KO females. Interestingly, there was a significant difference between gonadally intact WT males, WT castrated males and SF-1 KO males with gonadally intact WT males showing lower expression in comparison to both agonadal groups $(\mathrm{p}<0.05)$. There was no significant sex difference between gonadectomised WT males and females or SF-1 KO males and females (Figure 1).

\section{Cyp $4 a 10$}

As expected, the expression of Cyp4a10 was higher in livers from gonadally intact WT females in comparison to gonadally intact WT males ( $p<0.01$ ), but there was no difference in the expression in female livers during different stages of the estrous cycle. Absence of gonads in WT females and agonadal SF-1 KO mice resulted in the expression of Cyp4a10 similar to the levels observed in livers of all three groups of males and was significantly lower in comparison to the expression in gonadally intact WT females ( $p<$ 0.05). There was no significant difference between all three groups of male mice and there was no significant sex difference between gonadectomised WT males and females or SF-1 KO males and females. (Figure 2).

\section{Cyp2u1}

As expected the expression of Cyp2u1 was significantly higher in gonadally intact WT males in comparison to gonadally intact WT females regardless of the females' estrous cycle ( $p<$ 0.001) and there was no significant difference between females during different stages of the estrous cycle. Absence of gonads in females (in 


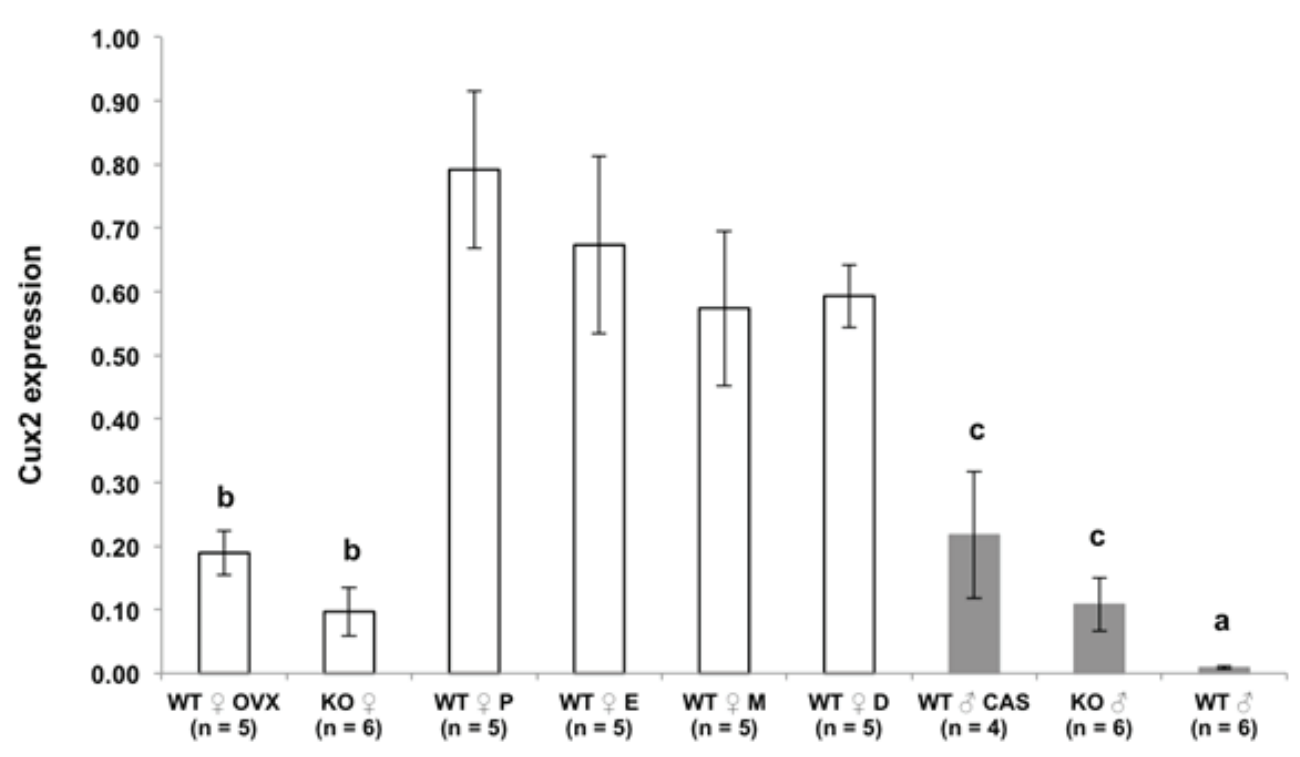

Figure 1: Expression of Cux2 was higher in gonadally intact WT females in comparison to gonadally intact WT males $(\mathrm{a}, \mathrm{p}<0.001)$ and to WT ovariectomized females and SF-1 KO females $(\mathrm{b}, \mathrm{p}<0.001)$ There was no significant difference between different stages of estrous cycle, however, expression in gonadally intact WT males was lower in comparison to WT castrated males and SF-1 KO males (c, p < 0.05; mean + S.E.M.; WT + OVX - WT ovariectomized females, $\mathrm{KO} q-\mathrm{SF}-1 \mathrm{KO}$ females, WT $q \mathrm{P}-$ gonadally intact WT females in proestrus, WT $q \mathrm{E}-$ gonadally intact WT females in estrus, WT $q$ M - gonadally intact WT females in metestrus, WT $q$ D - gonadally intact WT females in diestrus, WT $\hat{\jmath}$ CAS - WT castrated males, KO $\hat{\jmath}$ - SF-1 KO males, WT $\hat{\jmath}$ - gonadally intact WT males).

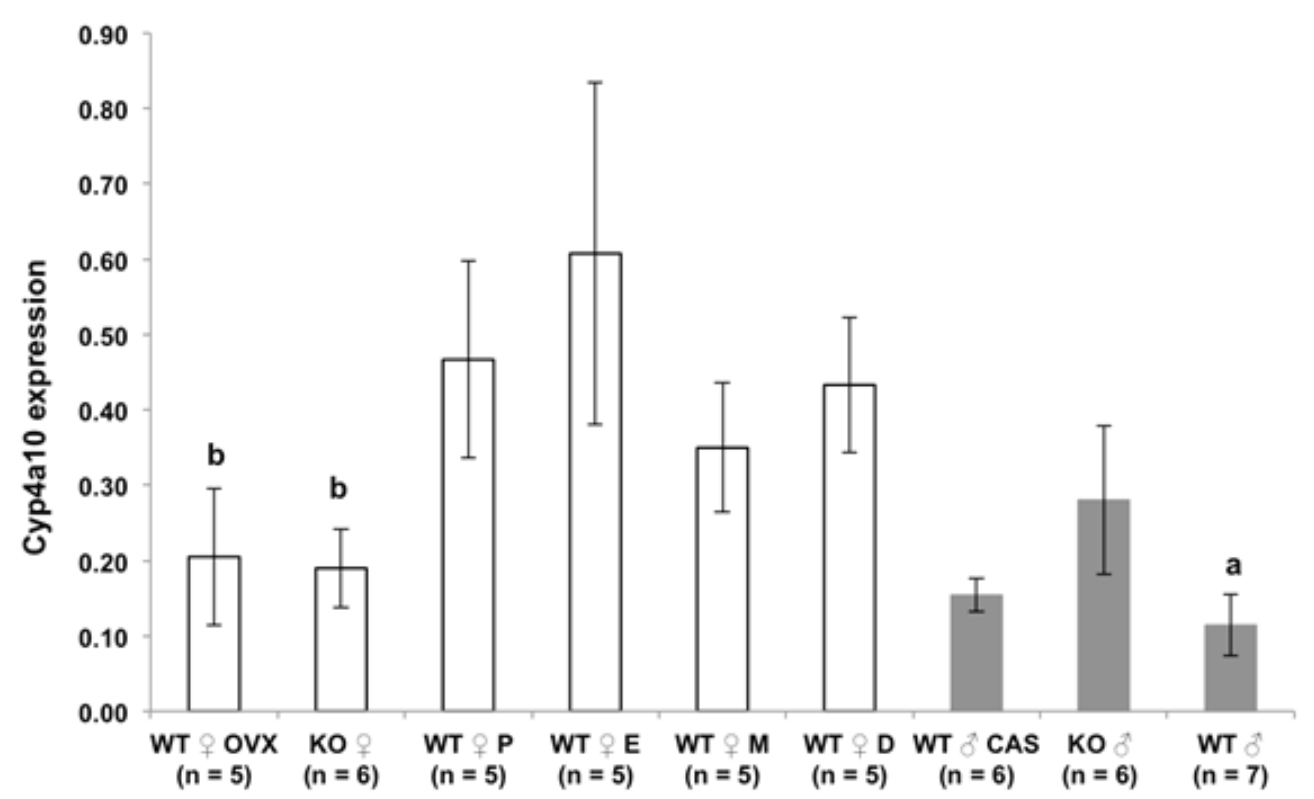

Figure 2: Expression of Cyp4a10 was higher in gonadally intact WT females in comparison to gonadally intact WT males $(a, p<0.01)$. There was no significant difference between females during different stages of the estrous cycle. The expression was significantly lower in both ovariectomized WT females and agonadal SF-1 KO females in comparison to the expression in gonadally intact WT females ( $b, p<0.05)$, and was similar to the expression level observed in all three groups of males. There was no significant difference between all three groups of males, or between WT gonadectomised males and females and SF-1 KO males and females (mean + S.E.M.; WT + OVX - WT ovariectomized females, KO $q$ - SF-1 KO females, WT $q$ P - gonadally intact WT females in proestrus, WT $q$ E - gonadally intact WT females in estrus, WT $q$ M - gonadally intact WT females in metestrus, WT $q$ D - gonadally intact WT females in diestrus, WT $\hat{\jmath}$ CAS - WT castrated males, KO $\hat{\jmath}-\mathrm{SF}-1 \mathrm{KO}$ males, WT $\hat{\jmath}-$ gonadally intact WT males). 


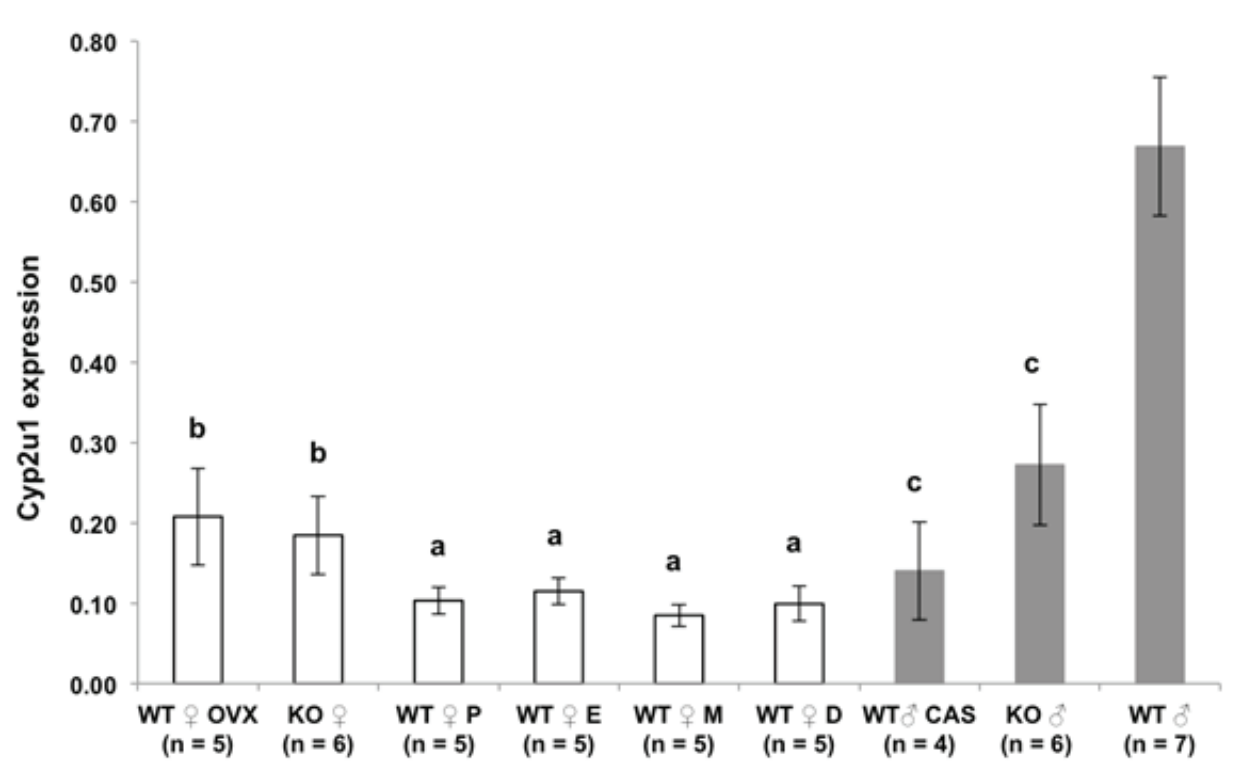

Figure 3: Expression of Cyp2u1 was higher in gonadally intact WT males in comparison to gonadally intact WT females regardless of the estrous cycle $(a, p<0.001)$, and there was no significant difference between different stages of the estrous cycle. WT ovariectomized females and SF-1 KO females showed significantly increased expression levels in comparison to gonadally intact WT females (b, $p<0.05)$ but lower in comparison to gonadally intact WT males. Expression in gonadally intact WT males was significantly higher in comparison to expression in both agonadal groups of males (WT castrated and SF-1 KO males, c, p < 0.001; mean + S.E.M.; WT $q$ OVX - WT ovariectomized females, KO $q$ - SF-1 KO females, WT $q$ P - gonadally intact WT females in proestrus, WT $q$ E - gonadally intact WT females in estrus, WT $q \mathrm{M}$ - gonadally intact WT females in metestrus, WT $q$ D - gonadally intact WT females in diestrus, WT ô CAS - WT castrated males, KO $\hat{\jmath}$ - SF-1 KO males, WT $\hat{\jmath}$ - gonadally intact WT males)

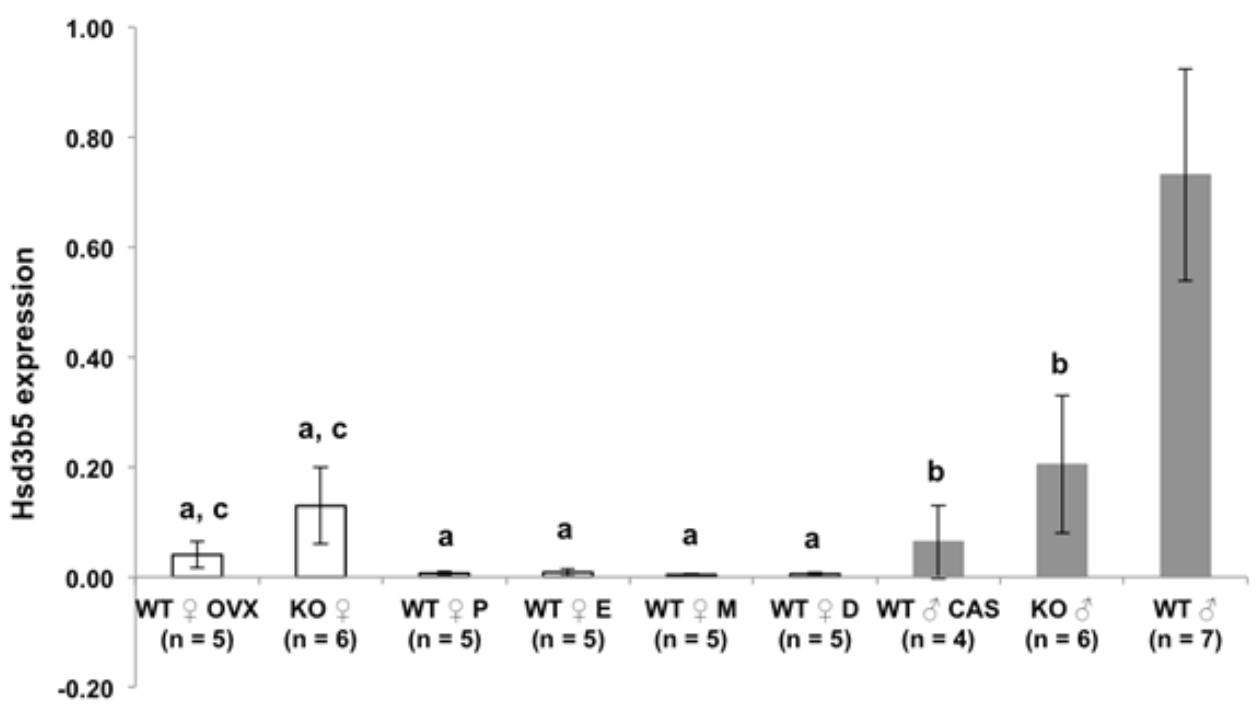

Figure 4: Expression of Hsd3b5 was significantly higher in gonadally intact WT males in comparison to all groups of females regardless of the estrous cycle $(\mathrm{a}, \mathrm{p}<0.001)$ and to both groups of agonadal males (WT castrated and $\mathrm{SF}-1 \mathrm{KO}$ males; $\mathrm{b}, \mathrm{p}<0.05)$. In gonadally intact females, there was no significant difference between stages of the estrous cycle, however, the expression was significantly higher in both ovariectomized WT and SF-1 KO females in comparison to the gonadally intact WT females (c, p < 0.01; mean + S.E.M.; WT + OVX - WT ovariectomized females, $\mathrm{KO}+$ - SF-1 KO females, WT $q$ P - gonadally intact WT females in proestrus, WT $q$ E - gonadally intact WT females in estrus, WT $q$ M - gonadally intact WT females in metestrus, WT $q$ D - gonadally intact WT females in diestrus, WT ô CAS - WT castrated males, KO ô - SF-1 KO males, WT ô - gonadally intact WT males) 
both WT ovariectomized females and SF-1 KO females) significantly increased the expression in comparison to gonadally intact females $(\mathrm{p}<0.05)$, but did not reach the levels observed in gonadally intact WT males. In males, there was significantly higher expression in gonadally intact WT males in comparison to both agonadal groups of males (WT castrated and SF-1 KO males, $\mathrm{p}<0.001$;). There was no significant sex difference between gonadectomised WT males and females or SF-1 $\mathrm{KO}$ males and females (Figure 3).

\section{Hsd $3 b 5$}

In accordance with previous studies, expression of Hsd3b5 was the highest in gonadally intact WT males and was significantly higher than in gonadally intact WT females regardless of females' estrous cycle $(p<0.001)$. There was no significant difference between females during the estrous cycle, but there was a significant difference between agonadal female mice (both WT ovariectomized and SF-1 KO) and gonadally intact female mice with agonadal WT ovariectomized and SF-1 KO female mice having higher expression of Hsd3b5 ( $<$ < 0.01). In male mice, the expression was significantly lower in SF-1 KO males and WT castrated males in comparison to gonadally intact WT males $(\mathrm{p}<0.05)$. There was no significant difference between gonadectomised WT males and females or SF-1 KO males and females (Figure 4).

\section{Discussion}

In the present study, the influence of sex hormones and sex chromosomes on mouse liver gene expression was examined. SF-1 KO mice that are born without gonads were used to investigate whether sex chromosomes play a role in the regulation of liver gene expression in addition to sex hormones. Results revealed significant differences in liver gene expression between sexes in gonadally intact WT animals, but not between SF-1 KO and WT GDX females and males. These findings therefore suggest that sex differences in the liver gene expressions are primarily influenced by sex hormones and not by sex chromosomes.

Many studies in the past have shown that gene expression in the liver is sexually dimorphic $(6$, 24). It is believed that these sex differences in liver gene expression mainly arise as a consequence of sexually dimorphic patterns of pituitary GH secretion at least in mice and rats $(8,7)$. GH is secreted in more pulsatile manner in males while its secretion from the pituitary in females is steadier. These differences in the secretion of GH are thought to be influenced by sex steroid hormones, namely estrogens in females and androgens in males (8). In males neonatal exposure to testosterone imprints the male pattern of the pulsatile pituitary GH secretion that is first seen at puberty and continues through adulthood. However, the presence of androgens is also necessary during adult life as in the absence of androgens, secretion pattern of growth hormone will show a feminine pattern in gonadectomised males (8).

Both estrogens and androgens can influence GH centrally by regulating pituitary GH secretion, but they can also influence the action of growth hormone peripherally by modulating the level of growth hormone receptor (GHR) expression and its signaling $(25,26)$.

Despite the established role for sex steroid hormones in the regulation of sex specific gene expression in the liver, possible influence of genes present on sex chromosomes on sex differences in the expression have not been reported. In the present study we have therefore chosen 4 genes, whose expression has been previously reported to be strongly sexually dimorphic, and examine their expression with regard to the exposure to sex steroid hormones during development and/or in adult life. Two of these genes, Cux2 and Cyp $4 a 10$ are expressed at the higher levels in females $(6,18$, 15-17) and Cyp2u1 and Hsd3b5 are expressed at the higher levels in male mice $(6,16,19)$. Cyp2u1 and Cyp $4 a 10$ are members of the cytochrome P450 family, which is comprised of hem-containing enzymes involved in metabolism of endogenous steroids and fatty acids, as well as detoxification of many drugs and environmental compounds (27). Similarly, like Cyp genes, Hsd3b5 gene is involved in steroid hormone metabolism (28), whereas the role of transcription factor Cux2 in the liver is to repress male-biased gene expression and induce female-biased gene expression (29).

Cux2 gene is a transcription factor that is believed to have a regulatory role in the sexually dimorphic liver gene expression. Previous studies have shown, that Cux2 directly regulates expression of many sexually dimorphic genes in 
the liver and is thus responsible for many sexual dimorphic gene expression patterns (18). In the present study, the expression of Cux 2 was higher in WT gonadally intact females in comparison to WT gonadally intact males, as expected. However, Cux2 gene expression did not differ during the estrous cycle as females in proestrus, estrus, diestrus and metestrus all show similarly high levels of expression of Cux2. Absence of gonads either through prepubertal gonadectomy of WT mice at 3 weeks of age, or in developmentally agonadal SF-1 KO mice reduced the level of expression in both agonadal males and females, suggesting that high expression in gonadally intact females is influenced by circulating female gonadal sexual hormones, estrogens and progestins. However, as there is no difference in Cux2 gene expression during the estrous cycle, this suggests that effects of estrogens (or possibly progestins) on liver gene expression of Cux2 gene are organizational and not activational. There was no difference in the expression of Cux2 between males and females in WT gonadectomised and in SF-1 KO mice, further confirming that gonadal hormones are necessary for sexually dimorphic expression of $\mathrm{Cux2}$, and there is no influence of sex chromosome genes on this expression. However, since WT males and females were gonadectomised only at three weeks of age, but there is no difference in the expression within the estrous cycle, this suggest that activational effects of gonadal hormones must not occur during classical organizational periods but later, during puberty or in early adulthood. Several studies indeed suggest that puberty is another period important for organizational effects of gonadal hormones in the brain (30). Although there are no reports about organizational effect of gonadal hormones on GH secretion patterns during puberty, it is possible that sexually dimorphic GH secretion pattern might develop during puberty and this could then influence sexually dimorphic liver gene expression. Interestingly, we also observed a significant difference in Cux2 expression in liver between WT gonadally intact males and both WT castrated males and SF-1 KO males. The expression was significantly lower in WT gonadally intact males in comparison to both agonadal males. This suggests that not only estrogens are involved in the regulation of Cux2 expression, but most likely testosterone further suppress this gene's expression levels. Whether this difference is due to differences in $\mathrm{GH}$ secretion patterns or due to direct effects of testosterone will have to be determined in the future studies.

Cyp 4 a 10 is a member of cytochrome $\mathrm{P} 450$ family with the function in xenobiotic metabolism (15). As with Cux2, we observed sexually dimorphic pattern of expression in gonadally intact WT mice only, and there was also no difference in the expression during the estrous cycle. Furthermore, expression of Cyp4a10 was reduced in both gonadectomised WT male and female mice, and agonadal SF- $1 \mathrm{KO}$ male and female mice, and there was no difference between these groups, again suggesting that sex chromosomes do not have a role in the sexually dimorphic expression. However, in contrast to Cux2 expression, expression levels of Cyp4a10 were similar between all three groups of males, suggesting that estrogens have the primary role in establishing sexually dimorphic gene expression pattern. Again, these roles must be primarily organizational as there was no difference between the females in different estrous cycle stage, but there is probably no influence of testosterone as there was no difference present between three groups of males.

As expected in accordance to previous results $(6,16)$, the expression of Cyp2u1 was significantly higher in gonadally intact males in comparison to gonadally intact females during different stages of the estrous cycle. This suggests that the main hormone regulating the expression of Cyp2u1 is testosterone, increasing expression of this gene either directly or through regulating pituitary $\mathrm{GH}$ secretion. In comparison to WT gonadally intact males, expression of Cyp2u1 was lower in both WT castrated males and SF-1 KO males. This suggests, that testosterone exposure after prepubertal development is responsible for higher expression of Cyp2u1 in gonadally intact WT males. Whether this higher expression is the result of direct activational effects by testosterone (directly or through GH secretion) in adult life, or perhaps through the organizational effects during puberty, remain to be determined in the future studies and was beyond the scope of this study. As with the other genes studied, there were no differences between gonadally intact WT females during the estrous cycle, again suggesting that estrogens or progestins do not have a direct, activational role in the regulation of expression of this gene in adult female mice. Interestingly, the expression in both WT ovariectomized females 
and SF-1 KO females was higher in comparison to gonadally intact females, suggesting that exposure to estrogens are also involved in the regulation of sexually dimorphic expression of Cyp2u1 by reducing the levels of expression of this gene.

The expression of Hsd3b5 was higher in WT gonadally intact males in comparison to gonadally intact females regardless of the estrous cycle, and to gonadectomised WT males and SF-1 KO males, again suggesting the direct role of testosterone in the regulation of sex specific expression of $H s d 3 b 5$. Interestingly, in female mice, similar to Cyp2u1, expression in WT gonadectomised and SF-1 KO females was significantly higher in comparison to gonadally intact females, again suggesting additional role of estrogens in the regulation of the expression of this gene, although direct regulation is unlikely, as there were no differences in the expression during the estrous cycle.

In general, results from this study suggest that sex differences in liver gene expression are consequence of different exposure to sex steroids and there is little, if any, role for the genes present on the sex chromosomes. Although we have studied only four genes, and therefore this does not rule out the possibility that the expression of some other genes might be influenced also by sex chromosomes, this is probably unlikely, firstly, because all the genes studied in the present study, showed somewhat similar patterns of expression with regard to sex and gonadal status, and secondly, because one of the studied genes, Cux2, is thought to be the regulator of male specific gene expression in the liver. Furthermore, results of the present study suggest, that sex differences are influenced by exposure to sex steroid hormones not during early developmental periods, similarly to numerous sex differences in the brain, but rather depend on adult activational, or perhaps pubertal organizational effects of sex steroid hormones. Although effects of testosterone on male specific expression of the studied genes might be purely activational, it is unlikely that effects of estrogens are purely activational, as we did not observe difference in the expression of any of the studied genes during the estrous cycle. This suggest that effects of estrogens on the expression of these four genes are not direct and acute, but rather some kind of organizational effects must be involved, either during pubertal period or in adult life.

In conclusion, the results of this study reveal that sex difference in the liver gene expression are dependent on adult (and possibly pubertal) exposure to sex steroid hormones in both sexes. For most of the genes studied, perhaps with the exception in Cyp4a10 expression in males, it also seems that both testosterone and estrogens are involved in the sex specific regulation, as gonadless mice from both sexes differ from the gonadally intact WT mice of respective sex. Since there were no sex differences in gene expression in either SF-1 KO mice or in prepubertally gonadectomised mice it seems that sex chromosomes, as well as early developmental exposure to sex steroid hormones, do not play a role in the regulation of sex difference in liver gene expression.

\section{Acknowledgements}

This study was supported by Grants P4-0053, J3-6801 and J7-7226 (ARRS, Slovenian research agency). Katja Kozinc Klenovsek was supported by $\mathrm{PhD}$ fellowship from the ARRS.

We would like to thank Nina Sterman for animal husbandry and technical assistance and to Dr. Klementina Fon Tacer for help with data analysis.

\section{References}

1. Li T, Huang J, Jiang Y, Zeng Y, He F, Zhang MQ et al. Multi-stage analysis of gene expression and transcription regulation in C57/B6 mouse liver development. Genomics 2009;93(3):235-42.

2. Clodfelter KH, Holloway MG, Hodor P, Park $\mathrm{SH}$, Ray WJ, Waxman DJ. Sex-dependent liver gene expression is extensive and largely dependent upon signal transducer and activator of transcription 5b (STAT5b): STAT5b-dependent activation of male genes and repression of female genes revealed by microarray analysis. Mol Endocrinol 2006;20(6):1333-51.

3. Wauthier V, Waxman DJ. Sex-specific early growth hormone response genes in rat liver. Mol Endocrinol 2008;22(8):1962-74.

4. Yates FE, Herbst AL, Urquhart J. Sex difference in rate of ring A reduction of delta 4-3-keto-steroids in vitro by rat liver. Endocrinology 1958;63(6):887-902.

5. Zhang Y, Laz EV, Waxman DJ. Dynamic, sex-differential STAT5 and BCL6 binding to sex-biased, growth hormone-regulated genes in adult 
mouse liver. Mol Cell Biol 2012;32(4):880-96.

6. Conforto TL, Waxman DJ. Sex-specific mouse liver gene expression: genome-wide analysis of developmental changes from pre-pubertal period to young adulthood. Biol Sex Differ 2012;3:9.

7. Waxman DJ, Holloway MG. Sex differences in the expression of hepatic drug metabolizing enzymes. Mol Pharmacol 2009;76(2):215-28.

8. Mode A, Gustafsson JA. Sex and the liver a journey through five decades. Drug Metab Rev 2006;38(1-2):197-207.

9. Gatti DM, Zhao N, Chesler EJ, Bradford BU, Shabalin AA, Yordanova $R$ et al. Sex-specific gene expression in the BXD mouse liver. Physiol Genomics 2010;42(3):456-68.

10. Lala DS, Rice DA, Parker KL. Steroidogenic factor I, a key regulator of steroidogenic enzyme expression, is the mouse homolog of fushi tarazu-factor I. Molecular Endocrinology 1992;6:1249-58.

11. Parker KL, Rice DA, Lala DS, Ikeda Y, Luo $\mathrm{X}$, Wong $\mathrm{M}$ et al. Steroidogenic factor 1: an essential mediator of endocrine development. Recent Prog Horm Res 2002;57:19-36.

12. Ingraham HA, Lala DS, Ikeda $Y$, Luo X, Shen W, Nachtigal MW et al. The nuclear receptor steroidogenic factor 1 acts at multiple levels of the reproductive axis. Genes and Development 1994;8:2302-12.

13. Luo X, Ikeda Y, Parker KL. A cell-specific nuclear receptor is essential for adrenal and gonadal development and sexual differentiation. Cell 1994;77:481-90.

14. Majdic G, Young M, Gomez-Sanchez E, Anderson P, Szczepaniak LS, Dobbins RL et al. Knockout mice lacking steroidogenic factor 1 are a novel genetic model of hypothalamic obesity. Endocrinology 2002;143(2):607-14.

15. Lee JS, Ward WO, Liu J, Ren H, Vallanat B, Delker D et al. Hepatic xenobiotic metabolizing enzyme and transporter gene expression through the life stages of the mouse. PLoS One 2011;6(9):e24381.

16. Renaud HJ, Cui JY, Khan M, Klaassen CD. Tissue distribution and gender-divergent expression of 78 cytochrome P450 mRNAs in mice. Toxicol Sci 2011;124(2):261-77.

17. Zhang Y, Klaassen CD. Hormonal regulation of Cyp4a isoforms in mouse liver and kidney. Xenobiotica 2013;43(12):1055-63.

18. Conforto TL, Zhang Y, Sherman J, Waxman DJ. Impact of CUX2 on the female mouse liver transcriptome: activation of female-biased genes and repression of male-biased genes. Mol Cell Biol 2012;32(22):4611-27.

19. Wong JS, Ye X, Muhlenkamp CR, Gill SS. Effect of a peroxisome proliferator on 3 beta-hydroxysteroid dehydrogenase. Biochem Biophys Res Commun 2002;293(1):549-53.

20. Dozmorov I, Bartke A, Miller RA. Array-based expression analysis of mouse liver genes: effect of age and of the longevity mutant Prop1df. J Gerontol A Biol Sci Med Sci 2001;56(2):B72-80.

21. Kwekel JC, Desai VG, Moland CL, Branham WS, Fuscoe JC. Age and sex dependent changes in liver gene expression during the life cycle of the rat. BMC Genomics 2010;11:675.

22. Pfaffl MW. A new mathematical model for relative quantification in real-time RT-PCR. Nucleic Acids Res 2001;29(9):e45.

23. Vandesompele J, De Preter K, Pattyn F, Poppe B, Van Roy N, De Paepe A et al. Accurate normalization of real-time quantitative RT-PCR data by geometric averaging of multiple internal control genes. Genome Biol 2002;3(7):RESEARCHO034.

24. Wiwi CA, Gupte M, Waxman DJ. Sexually dimorphic P450 gene expression in liver-specific hepatocyte nuclear factor 4alpha-deficient mice. Mol Endocrinol 2004;18(8):1975-87.

25. Fernandez-Perez L, Guerra B, Diaz-Chico JC, Flores-Morales A. Estrogens regulate the hepatic effects of growth hormone, a hormonal interplay with multiple fates. Front Endocrinol (Lausanne) 2013;4:66.

26. Meinhardt UJ, Ho KK. Modulation of growth hormone action by sex steroids. Clin Endocrinol (Oxf) 2006;65(4):413-22.

27. Jarukamjorn K, Sakuma T, Jaruchotikamol A, Ishino Y, Oguro M, Nemoto N. Modified expression of cytochrome P450 mRNAs by growth hormone in mouse liver. Toxicology 2006;219(13):97-105.

28. Nojima K, Sugimoto K, Ueda H, Babaya N, Ikegami H, Rakugi H. Analysis of hepatic gene expression profile in a spontaneous mouse model of type 2 diabetes under a high sucrose diet. Endocr J 2013;60(3):261-74.

29. Conforto TL, Steinhardt GFt, Waxman DJ. Cross Talk Between GH-Regulated Transcription Factors HNF6 and CUX2 in Adult Mouse Liver. Mol Endocrinol 2015;29(9):1286-302.

30. Sisk CL, Zehr JL. Pubertal hormones organize the adolescent brain and behavior. Front Neuroendocrinol 2005;26(3-4):163-74. 


\title{
RAZLIKE MED SPOLOMA V IZRAŽENOSTI GENOV PRI NAVADNIH MIŠIH IN MIŠIH Z IZBITIM GENOM SF-1
}

\author{
K. Kozinc Klenovsek, T. Spanic, G. Majdic
}

Povzetek: Razvoj in delovanje jeter sta odvisna od natančne izraženosti genov. Predhodne raziskave so pokazale, da so številni geni v jetrih različno izraženi med spoloma, te razlike pa naj bi bile vsaj delno posledica spolnih razlik vizločanju rastnega hormona. Cilj opisane raziskave je bil proučiti, ali tudi spolni kromosomi vplivajo na spolne razlike v izraženosti genov v jetrih. V raziskavi smo pri navadnih miših in miših z izbitim genom SF-1 (SF-1 KO) preverili izraženost genov Cyp4a 10, Cyp2u1, Cux2 in Hsd3b5, za katere je znano, da se v odraslih jetrih izražajo drugače pri samcih kot pri samicah. Miši SF-1 KO se rodijo brez spolnih žlez in zaradi tega niso nikoli izpostavljene spolnim hormonom, razlike med spoloma v izraženosti genov bi zato pri teh miših kazale na neposreden vpliv spolnih kromosomov. Dodatno smo primerjali med seboj tudi miši, ki smo jim odstranili spolne žleze, ter samice v različnih fazah spolnega cikla. Ugotovili smo višjo izraženost genov Cux2 in Cyp4a10pri navadnih samicah s spolnimi žlezamiv primerjaviz navadnimi samci s spolnimi žlezami. Ugotovili smo tudivišjo izraženost genov Cyp2u1 in Hsd3b5 pri navadnih samcih s spolnimi žlezami v primerjavi z navadnimi samicami s spolnimi žlezami. Nismo pa ugotovili vpliva odstranitve spolnih žlez ali vpliva izbitja gena SF-1 na spolne razlike, saj le-te niso bile prisotne ne med samci in samicami z odstranjenimi spolnimi žlezami kot tudi ne med samci in samicami z izbitim genom SF-1. Ti rezultati kažejo, da so vse razlike med spoloma vizraženosti genovv jetrih popolnoma odvisne od prisotnosti in vpliva spolnih hormonov, kijih proizvajajo spolne žleze.

Ključne besede: spolne razlike; jetra; izraženost genov; spolni hormoni, spolni kromosomi 